\title{
Cultura e tradição em Gilberto Freyre: esboço de interpretação do Manifesto regionalista
}

\author{
Robson dos Santos \\ Doutorando em Sociologia (Universidade de Campinas) \\ Professor do Departamento de Ciências Sociais da Universidade Federal de Rondônia \\ relvalins@yahoo.com.br
}

\begin{abstract}
Resumo Neste artigo buscamos analisar aspectos da defesa da tradição cultural nordestina levada a cabo no Manifesto regionalista, escrito por Gilberto Freyre em 1926. O texto de Freyre se insere no debate sociocultural do campo intelectual de então, por meio de uma intervenção destacada nas discussões sobre o modernismo. Buscamos também explicitar como o Manifesto opera, em certa medida, um resgate do passado rural colonial, desenvolvendo naquele momento um confronto entre tradição e modernidade, compondo, dessa forma, uma estratégia relativamente conservadora de interpretação das transformações sociais.
\end{abstract}

Palavras-chave: tradição; rural; urbano; regionalismo; modernismo

\section{O solo dos debates}

A penosa construção de nós mesmos se desenvolve na dialética rarefeita entre o não ser e o ser outro.

(Paulo Emílio Salles Gomes)

\begin{abstract}
A história intelectual brasileira é profundamente marcada pelo debate cultural e político em torno das noções de "autenticidade" ou "imitação", criação original ou cópia, importado ou nativo, enfim, polos intelectuais que cristalizam visões de mundo e posições estéticas antagônicas. Tal discussão possui presença marcante nos campos culturais, principalmente naqueles onde emergem as criações artísticas e literárias. A problemática se concentra em estabelecer uma diferenciação entre as produções que se "articulam com a realidade local", expondo de forma autêntica as características mais essenciais do país, daquelas produções que se limitam a reproduzir uma "imitação" das criações originárias dos centros culturais capitalistas. "Essa experiência tem sido um dado formador de nossa reflexão crítica desde os tempos da Independência" (Schwarz, 1987, p. 29).

É evidente que a questão não se restringe aos aspectos inerentes ao conteúdo das obras culturais, mas amplia-se para a própria discussão sobre o que funda a identidade nacional, a "realidade brasileira", a matéria propriamente dita das obras. No entanto, a definição do que seja o "autêntico" nacional perpassa e exprime as posições dos grupos que a encampam em contextos diversos da história intelectual e social do país. De qualquer forma, a questão se refere à própria constituição histórica do país e à busca que a acompanha de uma "compreensão" endógena de suas instituições e práticas sociais em dialética com o discurso fundante do colonizador:
\end{abstract}


Como "explicar" a "nossa constituição"? [...] Ou bem nos explicamos, ou bem nos construímos - eis o falso dilema para o intelectual brasileiro, que gera - na sua simplificação - todas as formas de discurso autoritário entre nós, tanto o populista quanto o integralista. (Lima, apud Gomes, 1981, p. 14)

A busca da triagem entre o "original e a cópia", entre a "sociedade dos outros" e a "nossa", demanda da análise cultural um exercício de análise das criações que "incorporam" e expressam a identidade, ou o caráter nacional brasileiro, conforme o já clássico estudo de Leite (1969). Nesse sentido, a compreensão dos aspectos fundadores e da "essência" da nacionalidade sempre foi uma obsessão entre os agentes intelectuais, sobretudo entre os "intérpretes" do Brasil, principalmente até a primeira metade do século XX. Em momentos distintos da história cultural do país e das conformações sociais do campo intelectual, o tema reaparece nas discussões literárias ou sociológicas com grande vigor. Ele mobiliza diversos dos principais intelectuais brasileiros ${ }^{1}$ e formata, inclusive, a própria substância dos debates no seio dos campos de produção discursiva, como o intelectual e o literário. É evidente, porém, que a reinvenção do passado comporta, por vezes, uma luta da heterodoxia do campo em busca das posições de ortodoxias, mas não se esgota aí. Afinal, a própria reinvenção do passado pode ser uma forma de recomposição e revigoramento das forças políticas do presente (Marx, 1997).

No contexto dos anos 20 e 30, as problemáticas da nação e da identidade nacional irrompem com vigor e ganham uma centralidade no seio do modernismo em solo brasileiro. A "necessidade" inerente ao campo intelectual de estabelecer uma definição "do que é a nação", almejava, entre outras questões, fomentar a consolidação de "uma cultura nacional", "autêntica" e emancipada das fontes europeias, ou ao menos capaz de efetivar uma reinterpretação dessas, sem, contudo, reestruturar as práticas sociais.

Os modernistas ${ }^{2}$ buscavam contribuir com a "construção da nação" e dar-lhe um sentido por meio de um conhecimento aprofundado das especificidades culturais do país, operando uma releitura do passado colonial, da cultura indígena e africana, entre outras, a fim de disponibilizar o substrato discursivo e ideológico de nossa formação social. Antes de "construirmos" uma sociedade nacional, era preciso inventariar nossas tradições e expressões culturais e "coletar" dados acerca de nossa composição social. Para isso, recorria-se à edificação de obras que resgatassem o que consideravam os aspectos mais característicos da cultura nacional, ou seja, o folclore, a linguagem popular, as tradições indígenas e rurais do país etc.

A "autenticidade", portanto, era um privilégio do passado. No romantismo, a procura do indígena do século XIX, no modernismo folclorista da década de XX e no romantismo revolucionário das décadas de 1950 e1960 (Ridenti, 2000), o que emerge é a perseguição dos resquícios de autenticidade nos espaços, tempos e agentes característicos do passado, da tradição e/ou do atraso. Estes eram buscados, principalmente, nos interiores e espaços rurais do país, como bem analisou Lima (1999).

No seio dessas discussões também emergem intelectuais aglutinados ao redor do regionalismo nordestino, que irrompeu nos anos 20 na capital pernambucana Recife, que era um dos centros intelectuais do país e se contrapunha, em certa medida, à centralidade do Rio de Janeiro e de São Paulo. Essa variação do chamado regionalismo era atrelada à figura de Gilberto Freyre, seu principal agitador e representante intelectual. Esse movimento caracterizava-se pela valorização das especificidades locais nordestinas e atingiu amplo destaque entre os polos intelectuais do país.

O objetivo explícito, entre outros, era compor uma defesa e a preservação de tradições rurais patriarcais nordestinas vislumbradas pelos intelectuais que gravitavam ao redor das ideias cristalizadas no $\mathrm{Ma}$ nifesto regionalista, redigido por Freyre, como as mais representativas da organização social e cultural do país e do que conformava a identidade e a "genética" cultural da nação.

Nesse sentido, buscamos aqui entender como as ideias de tradição, autêntico e inautêntico - materializadas e ilustradas em referências ao rural e ao urbano - aparecem em um momento da obra de Gilberto Freyre, mais especificamente no Manifesto regionalista e na proposta de regionalismo desenvolvida por ele. Essa, porém, só pode ser compreendida no interior dos confrontos intelectuais de então e das transformações sociais às quais são remetidas, explícita ou implicitamente, tal como a dissolução do poderio dos produtores canavieiros, a construção da República, a emergência da urbanização e da industrialização, dos movimentos operários, entre outros.

O Centro Regionalista do Nordeste, fundado em 1924, era encabeçado por Freyre e intencionava representar um polo de investigação e preservação das tradições socioculturais nordestinas, ressaltando como elas retinham as características mais destaca- 
das e autênticas do "povo brasileiro". Ele congregava um conjunto de intelectuais e almejava compor um programa de intervenção. Analisando o Manifesto do grupo, buscamos compreender como o movimento se opõe ao modernismo paulista e em que medida a preservação das tradições regionais se vinculava a uma determinada concepção social ainda enraizada no poderio rural e tingida por elementos conservadores.

Ao resgatar as proposições do Manifesto, a intenção não é compor uma deslegitimação da obra de Gilberto Freyre, ou mesmo uma síntese de suas produções e das visões de mundo que as caracterizam ao longo dos textos posteriores. Longe disso. O intento específico é localizar o sentido das proposições do Manifesto no interior das disputas, debates intelectuais e das práticas sociais que informavam o universo cultural brasileiro nas primeiras décadas do século XX, mais especificamente no contexto modernista.

\section{O Manifesto regionalista e identidade nacional: signos do "rural autêntico" e do "urbano inautêntico"}

O regionalismo que irrompe no Manifesto regionalista difere daquele que ressoará em parte do romance nordestino da década de 1930. Muitos dos títulos que acabaram por receber o rótulo de regionalistas possuem uma perspectiva absolutamente diversa $\mathrm{da}$ sugerida pelo Manifesto. Coincidem no ponto de partida, o Nordeste, mas se opõem nas conclusões críticas quanto à situação social da região. ${ }^{3}$ É claro que, em alguns autores, as propostas do regionalismo de Freyre possuem uma grande ressonância, não como aplicação de um programa sociopolítico nas elaborações estéticas, mas como signos compartilhados de um ambiente intelectual e de percepção das transformações sociais.

Em 1926 ocorria na cidade de Recife o I Congresso Brasileiro de Regionalismo, resultado de reuniões entre intelectuais simpáticos à ideia e que se encontravam, desde 1923, na casa de Odilon Nestor. Entre eles, destacavam-se Gilberto Freyre e José Lins do Rego. Estes se consolidariam como os principais representantes do "movimento", tomando esse termo num sentido bastante limitado, pois não é possível conferir a ele uma sequência linear e organizada.
Freyre desenvolveria ao longo de sua carreira uma vasta e decisiva obra de interpretação do Brasil que enxerga na região Nordeste um dos pilares originais da cultura e da sociedade brasileira, assim como as bases de nossa formação (D’Andrea, 1992; Morais, 2005). Foi justamente durante o Congresso realizado pelo grupo em 1926 que Freyre leu o texto que ficou conhecido como Manifesto regionalista ${ }^{4}$ e que, com algumas alterações, seria publicado somente em 1951 (D’Andrea, 1992).

A importância simbólica do Manifesto fica patente quando vislumbrada no contexto dos anos 20 e a partir dos debates que busca estabelecer diante dos discursos intelectuais em voga. O "pano de fundo" é a modernização capitalista que "dá seus primeiros passos" no decênio de 20, com a ampliação dos aglomerados urbanos, a expansão das relações mercantis, a urbanização e a decadência já em estado avançado da grande produção canavieira do Nordeste. As disposições que definiam o campo intelectual giravam, em certa medida, ao redor dos debates advindos com a "renovação" estética e cultural propugnada pela chamada Semana de Arte Moderna de 1922, ocorrida em São Paulo.

O modernismo, por sua vez, sugere um aspecto da mobilização intelectual quanto às possibilidades do progresso durante a República Velha e apontava para o esgotamento dos modelos estéticos hegemônicos durante o período. É, em certa medida, no contexto de abundância gerada pela produção cafeeira e de industrialização de alguns pontos do país, que emergem as possibilidades de uma ruptura com as tradições intelectuais consagradas e dominantes desde o final do século XIX. As vanguardas europeias passam a contar com uma forte influência nos espaços intelectuais brasileiros desde o início do século XX, através de diversas correntes modernistas, tais como o futurismo. A ruptura com o parnasianismo e o simbolismo na literatura constitui a frente de confronto mais destacada (Bosi, 1979).

É importante ressaltar ainda que o poder econômico da região Nordeste havia entrado em decadência desde a segunda metade do século XIX, com o enfraquecimento da produção canavieira e com a concentração estatal e produtiva no Sudeste/Sul do país. O engenho de açúcar tornava-se cada vez mais obsoleto, como forma de produção, diante das usinas industrializadas. Estas trazem consigo não apenas incrementos de ordem técnica, mas também uma nova forma de racionalização do trabalho e das relações sociais entre proprietários e trabalhadores. Substituem

3. Quanto a esta questão ver Almeida (1999) e D'Andrea (1992).

4. Utilizaremos a sigla MR para nos referirmos ao Manifesto nas citações. A cópia utilizada não possui paginação. O acesso foi feito em fevereiro de 2010 e confirmado em janeiro de 2011. Disponível em: <http://www.arq.ufsc.br/arq5625/modulo2modernidade/manifestos/ manifestoregionalista.htm>. 
a dominação patriarcal pela exploração capitalista. O habitus de dominação do senhor de engenho é trocado, gradualmente, pelo do burguês.

Se sob um prisma puramente econômico elas representaram um progresso, social e culturalmente o efeito foi negativo. O usineiro constitui com frequência um elemento adventício, sem vício com a região, e o esquema puramente capitalista e impessoal dessa nova forma de produção torna-se um fator a mais para apressar a dissolução da sociedade patriarcal e paternalista que durante mais de três séculos se desenvolvera em torno da cana. (Almeida, 1999, p. 194)

Dessa forma, é a um quadro de alterações das estruturas sociais e econômicas que o Manifesto regionalista se reporta. Afinal, a possibilidade de consolidação de um mercado de bens simbólicos exige uma rede de estruturas sociais, de bases materiais indispensáveis para as "formações culturais", que entram em processo de conflito e contradição diante de quadros de afluência das possibilidades de circulação cultural (Williams, 2000). ${ }^{5}$ Sua redação, nos anos 20 , mais especificamente em 1926, ocorre num momento avançado da situação acima referida, em que os antigos engenhos não mais imperavam na paisagem física e social do Nordeste e no qual o mundo rural dá espaço cada vez mais ao urbano. Esse processo de alterações sociais ganharia um retrato aprofundado nos chamados romances do ciclo da cana, de José Lins do Rego, que, não por acaso, foi um dos principais "militantes" do regionalismo freyreano. Não só no romance, mas também na poesia, é possível rastrear o tema da mecanização e da modernização usineira no Nordeste. Em Jorge Lima, por exemplo, tal questão surge de maneira destacada em versos tomados por um saudosismo melancólico.

\section{Cadê você meu país do Nordeste}

que eu vi nessa usina Central Leão de minha terra

Ah! Usina, você engoliu os bangüêzinhos do país das

Alagoas!

Você é grande, Usina Leão!

Você é forte, Usina Leão!

As suas turbinas têm o diabo no corpo!

\author{
Você uiva! \\ Você geme! \\ Você grita! \\ Você está dizendo que U.S.A. é grande! \\ Você está dizendo que U.S.A. é forte! \\ Você está dizendo que U.S.A. é única! \\ Mas eu estou dizendo que V. é triste \\ como uma igreja sem sino, \\ que você é mesmo como um templo evangélico [...] \\ [...] Ah! Usina Leão, você enguliu [sic] \\ os banguezinhos do país das Alagoas. (Lima, 1958, \\ p. 352).
}

As mutações pareciam ser amplas e profundas o suficiente para não confluírem numa alteração das diversas instâncias sociais e culturais. O MR parece vislumbrar tal situação com certa clareza e articula-se num discurso crítico e temeroso em relação às mutações que vislumbra. Não se refere explicitamente à superação técnica dos engenhos e à modernização das relações de produção e das forças produtivas, mas é sobre a dissolução e as transformações culturais que acompanham a nova situação que ele irá se concentrar ao adentrar no debate sobre a identidade nacional. "Como se explicaria, então, que nós, filhos de região tão criadora, é que fossemos agora abandonar as fontes ou as raízes de valores e tradições de que o Brasil inteiro se orgulha ou de que se vem beneficiando como valores basicamente nacionais?” (MR, não paginado).

Dito de outra forma, para o autor, é na região rural do Nordeste dos antigos engenhos que a nação foi gestada e cultivada. Logo, nada mais natural que fornecesse as referências àquilo que de mais autêntico define a cultura nacional. O Manifesto alimenta-se do passado, ${ }^{6}$ extraindo dele as armas utilizadas no combate da sua contemporaneidade. Aqui, é o passado nordestino-pernambucano que será concebido como portador das características mais profundas da nação. Esse passado, porém, não configura uma simples abstração de um tempo remoto, mas se refere ao contexto colonial e à cultura canavieira.

O debate que o Manifesto propõe realiza-se principalmente em oposição ao Modernismo de 1922 mais entrincheirado no Sudeste (Rio e São Paulo) - e delimita os polos geográficos do campo intelectual

\footnotetext{
5. Cabe notar que tal vinculação entre estruturas sociais e bens simbólicos não remete a noção de reflexo, mas sim à necessária compreensão da articulação entre condições sociais e cultura. A produção e a reprodução das ideias e dos bens simbólicos é instância fundamental para a compreensão das formações culturais. A força das ideias, contudo, não pode ser tomada como um tipo de determinismo idealista, comum em certa sociologia das motivações culturais, e da produção de ethos que produz novos ethos, num ciclo do "espírito" como a nova essência das relações sociais. É preciso articular as dimensões relativamente autônomas da cultura, com as condições materiais de emergência de possibilidades e impossibilidades culturais. A título de hipótese, é interessante notar a correlação entre os polos hegemônicos do campo cultural ao longo da história e a existência de um conjunto de condições sociais para tal: o nordeste na colônia; Minas Gerais com o barroco durante o ciclo do ouro; o Rio de Janeiro durante o Império e o Período Republicano.
}

6. A referência ao passado, por vezes, ganha ares de romantismo no Manifesto. Não é essa a perspectiva que buscamos analisar aqui, apesar das possibilidades que a sugestão possui. Não queremos com isso sugerir que toda afirmação do presente, do moderno, ou do futuro seja progressista ou crítica se comparada à do passado. 
de então. A partir de tal oposição, Freyre busca não apenas apontar os valores culturais mais "autênticos" da região Nordeste, mas também mobilizar as forças intelectuais da região na defesa da "tradição". $\mathrm{Na}$ síntese de D'Andrea, os conflitos sociais, políticos e econômicos implícitos no debate cultural do Regionalismo nordestino surgem de maneira cristalina:

Tradicionalismo via colonização portuguesa, tradição via patriarcalismo é a tônica da ideologia da ordem na década de 20 aqui no Brasil, do ponto de vista do regionalismo-tradicionalista nordestino. Em torno desses interesses urgia lutar contra as forças desagregadoras do declínio rural. Mercê de uma visão apaixonada e a-histórica, são metidas no mesmo saco as "causas" dessa desagregação: a República que implantara o Estadualismo, trazendo como consequência a descentralização regional, o progresso burguês, o positivismo, o liberalismo, o cientificismo, o militarismo, a democracia liberal e o "futurismo". (D’Andrea, 1996, p. 83)

É verdade que a preocupação inicial de Freyre é afastar qualquer conotação política das discussões regionalistas, afinal, "toda terça-feira, um grupo apolítico de Regionalistas vem se reunindo na casa do Professor Odilon Nestor, em volta da mesa de chá com sequilhos e doces tradicionais da região" (MR, não paginado). Esta preocupação se traduziria numa perspectiva social do movimento: "E esse sentido por assim dizer eterno em sua forma - o modo regional e não apenas provincial de ser alguém de sua terra - manifestado numa realidade ou expresso numa substância talvez mais histórica que geográfica e certamente mais social do que política (MR, não paginado, grifo nosso).

No entanto, é paradoxal a tentativa de destacar o movimento regionalista de Freyre como "um grupo apolítico", na medida em que, após a apresentação dos principais envolvidos, o autor passa a desferir críticas justamente ao "estadualismo republicano" e a dar um encaminhamento cada vez mais programático ao movimento. Isto o insere diretamente nos debates de então sobre República e Federação, sobre a nação e a região, questões tão em voga na discussão nacionalista e liberal do contexto:

A maior injustiça que se poderia fazer a um regionalismo como o nosso seria confundi-lo com separatismo ou com bairrismo. Com anti-internacionalismo, antiuniversalismo ou antinacionalismo. Ele é tão contrário a qualquer espécie de separatismo que, mais unionista que o atual e precário unionismo brasileiro, visa a superação do estadualismo, lamentavelmente desenvolvido aqui pela República - este sim, separatista - para substituí-lo por novo e flexível sistema em que as regiões, mais importantes que os Estados, se com- pletem e se integrem ativa e criadoramente [sic] numa verdadeira organização nacional. (MR, não paginado)

A política está presente no texto na forma de um projeto de integração nacional que supere a fragmentação dos estados e se consolide a partir dos diversos regionalismos. Esses são localizados, portanto, não na divisão cartográfica e administrativa do país, mas nos múltiplos sistemas e conjuntos culturais que se distribuem no território nacional.

O conjunto de regiões é que forma verdadeiramente o Brasil. Somos um conjunto de regiões antes de sermos uma coleção arbitrária de "Estados", uns grandes outros pequenos, a se guerrearem economicamente como outras tantas Bulgárias, Sérvias e Montenegros e a fazerem as vezes de partidos políticos - São Paulo contra Minas, Minas contra Rio Grande do Sul - num jogo perigosíssimo para a unidade nacional. (MR, não paginado)

O pano de fundo das intenções "antibeligerantes" contidas no trecho acima talvez se caracterize pela necessidade de inverter os termos do debate sobre nação travados no seio dos modernismos de então. Por um lado, o fato é que o poderio patriarcal do Nordeste canavieiro não mais possuía qualquer vigor econômico para sustentar uma política de oposição à dominação da produção cafeeira e sua política de socialização das perdas, típica da República Velha. Por outro lado, a oposição ao federalismo se fazia pela dissolução da noção de Estado, focando-se principalmente em algo mais amplo e fluido como a noção de região cultural. Assim, não é por acaso que qualquer forma de sociabilidade contrária ou diversa das que constituem a herança colonial e canavieira de alguns espaços do Nordeste será rechaçada como anomalia, estrangeirice, desajuste ou imitação irrefletida. Nesse sentido é que os ideais republicanos são vislumbrados: não servem à sociedade brasileira, pois estão em desajuste com nossa natureza, estranha às "roupagens republicanas", "roupas feitas, roupagens exóticas, veludos para frios, peles para gelos que não existem aqui” (MR, não paginado).

Aparentemente, a contradição que incomoda o sociólogo pernambucano não é a da República sem um povo, ou seja, a que exclui a ampla maioria da população, mas a que enfraquece, brandamente, os poderes regionais. Tal contradição possui uma relevância paradigmática na história sociopolítica do país, pois exigiu dos chefes políticos brasileiros um exercício de adaptação dos ideais republicanos à organização e à conformação social brasileira.

O liberalismo brasileiro, no entanto, só pode ser entendido com referência à realidade brasileira. Os liberais brasileiros importaram princípios e fórmulas po- 
líticas, mas as ajustaram às suas próprias necessidades [...]. No Brasil, os principais adeptos do liberalismo foram homens cujos interesses se relacionavam com a economia de exportação e importação. Muitos eram proprietários de grandes extensões de terra e elevado número de escravos. (Costa, 1985, p. 132-133)

Não são gratuitas, portanto, as acusações dirigidas à "estranhice" e as cópias modernas expressas pelo modernismo do Sudeste. De acordo com o Manifesto, é necessário preservar do ataque o que de mais sincero nos foi relegado pelo passado colonial. É esta preservação que orienta o texto e que o conduz a um resgate das bases da nação e da identidade de nossa cultura:

Uma cultura que, em última instância, repousa no mito colonizador; no passado de além-mar; na dependência de uma tradição cultural impostas, assimilada e totalmente acrítica. O manejo ideológico torna-se eficaz quando, mercê de uma identificação com o colonizador, elege-se o passado como autenticamente brasileiro. Torna-se o passado um presente contínuo que se mantém enquanto tradição revitalizada por valores e hábitos culturais moldados à feição do figurino da dependência colonizadora. Passado também enriquecido pelo fascínio do recém-abolido regime monárquico brasileiro. (D’Andrea, 1992, p. 43)

Se o Brasil, ou seus movimentos intelectuais e políticos, mantém um constante processo de importação de ideias e comportamentos, resta então encontrar e destacar o que define a verdadeira nação brasileira. Cada polo do debate intelectual de então buscava oferecer uma resposta para tal indagação:

A verdade é que não há região no Brasil que exceda o Nordeste em riqueza de tradições ilustres e em nitidez de caráter. Vários dos seus valores regionais tornaram-se nacionais depois de impostos aos outros brasileiros menos pela superioridade econômica que o açúcar deu ao Nordeste durante mais de um século do que pela sedução moral e pela fascinação estética dos mesmos valores. (MR, não paginado)

Como ressalta o próprio texto, os valores e tradições locais compõem a fundamentação da nação, neles essa encontra seus principais sustentáculos. As influências emergem de regiões e culturas variadas (portuguesa, holandesa, africana, indígena, oriental, etc.), e é no Nordeste que se mesclam completamente formando aquilo que o "Brasil inteiro se orgulha ou de que vem se beneficiando como de valores basicamente nacionais" (MR, não paginado, grifo nosso). Mais adiante Freyre enfatiza essa importância: “o
Nordeste tem o direito de considerar-se uma região que já grandemente contribuiu para dar à cultura ou à civilização brasileira autenticidade e originalidade e não apenas doçura ou tempero" (MR, não paginado).

No campo sociológico, Freyre busca articular o micro e o macro na análise da configuração da nação. Isso, em partes, já aparece em sua orientação intelectual do Manifesto. Segundo Ianni (2002), em tal linha do pensamento social brasileiro, do qual Freyre é o maior expoente, o Brasil é visto como um país marcado pelo patriarcalismo, que se forma e desenvolve no curso dos séculos de escravismo, com desdobramentos no coronelismo, caciquismo e oligarquia tudo isso no âmbito de algo denominado lusotropicalismo. Isto tudo, ainda segundo Ianni, sem esquecer a contínua e reiterada associação, mescla ou confusão entre o privado e o público. A herança dos tempos mortos pesa sobre a consciência dos vivos e é o passado cultural a chave para a compreensão de nossa "identidade nacional".

Resgatando e ressaltando o que de mais original a região canavieira nordestina relegou à cultura nacional, o Manifesto regionalista parece almejar, como bem definiu Ortiz (1985), fornecer ao brasileiro uma carteira de identidade, um $R G$ da nacionalidade, algo que atestasse sua peculiaridade. Tal proposição insere o texto de Freyre profundamente no horizonte discursivo, no sistema de disposições que conformavam o campo intelectual brasileiro, em suas variadas regiões e poderes de fala. Lança ele ainda como um contraponto explícito a variação paulista do modernismo.

O paradoxal é que a importação de comportamentos e práticas transladadas pela colonização abarcava a "inovação" escravista e outras sociabilidades europeias, lembremos o cristianismo, e é isto que alimenta a "pureza e autenticidade" da nação brasileira. A estas importações o texto não se refere. No Manifesto somente a importação cultural recente assume uma condição negativa àquela operada em um passado distante, diga-se colonial, e confunde-se, porém, com a autenticidade. O modernismo e a República, no entanto, são vestimentas estranhas à harmonia tropical. A contradição, contudo, ganha ares adocicados e aos poucos vai sendo diluída pela redação do Manifesto, no inigualável estilo de Freyre.

Apontar os valores mais genuínos da nação exige que Freyre destaque empiricamente então onde residem tais influências, assim quais as formas pelas quais elas se imbricam à sociedade brasileira. Aqui ganha destaque a descrição e o inventário detalhado, assim como, em última instância, a celebração dos mucambos $^{7}$ e da culinária originária da cultura patriarcal-canavieira. 
Para Freyre, o mucambo é uma forma de habitação superior, nas condições tropicais, a qualquer outro estilo residencial. "É que o mucambo se harmonisa [sic] com o clima, com as águas, com as cores, com a natureza, com os coqueiros e as mangueiras, com os verdes e os azues da região como nenhuma outra construção" (MR). Se a estética dessa construção coberta de palha merece elogios técnicos, ${ }^{8}$ a seu conteúdo nenhuma referência é feita. O mucambo parece ser, segundo o Manifesto, apenas uma opção arquitetônica e decorativa, que adaptou-se formidavelmente ao calor nordestino. O único problema em relação a ele é a localização em que normalmente se encontra: mangues, favelas etc. Rústico, mas funcional, o mucambo é "habitação superior a esses tristes sepulcros nem sempre bem caiados que são, entre nós, tantas casas de pedra e cal [...] dentro das quais vive vida breve ou morre aos poucos a maior parte da gente média da região, nas cidades e até nos povoados" (MR). Tal harmonia ganha status de valores superiores e como tais deixam de ser apenas um valor e uma forma de construção para tornar-se um valor nacional e um componente de sua autenticidade:

O mucambo é um desses valores. Valores pelo que representa de harmonisação [sic] estética: a da construção humana harmonisada com a natureza. Valor pelo que representa de adaptação higiênica, a do abrigo humano adaptado à natureza tropical. Valor que representa como solução econômica do problema da casa pobre: a máxima utilização, pelo homem, da natureza regional, representada pela madeira, pela palha, pelo cipó, pelo capim fácil e ao alcance dos pobres. (MR, não paginado)

O processo de desenvolvimento capitalista implica, entre múltiplas dimensões, uma modernização arquitetônica, buscando oferecer aos aglomerados urbano-industriais uma funcionalidade coerente com as necessidades de circulação econômica e social e com as estratégias de dominação que as acompanham. Berman (1996) aponta as transformações ocorridas nas principais cidades industriais da Europa, no século XIX, onde a modernização exigiu um remodela- mento do espaço urbano, que passava a ter de responder às necessidades surgidas com o desenvolvimento capitalista. Nesse contexto, antigas construções foram demolidas para dar lugar ao fluxo das largas avenidas, capazes de permitir uma fluência maior do intenso ir e vir pelas cidades e aperfeiçoar os mecanismos de disciplinamento social. As cidades passavam a assumir uma nova configuração, assim como as sociabilidades que as caracterizavam se alteravam.

No Brasil, o contexto e a forma de execução diferem do caso europeu. Porém, não deixa de ser frutífero resgatar, sucintamente, esse momento para pensarmos o caso brasileiro. Aqui a modernização redundava em reformulações urbanas que dissolviam não apenas os mucambos, mas alteravam a própria estrutura colonial de algumas cidades brasileiras, entre elas o Recife, com suas "velhas ruas estreitas do Nordeste", que, "bem situadas, são entre nós, superiores não só em pitoresco como em higiene às largas" (MR, não paginado). É contra essa face da modernização que o Manifesto também se levantará, recorrendo à noção de "inadaptação" estrutural, isto é, uma desarticulação entre as formas estéticas da arquitetura modernista e o conteúdo cultural e social nacional.

O que Freyre repele não são as grandes avenidas. Reconhece sua necessidade em cidades desenvolvidas e de amplas dimensões, mas recusa os modelos estrangeiros. Novamente a questão da imitação é mobilizada ${ }^{9}$ como estratégia de oposição à modernização. As ruas largas são "avenidas incaracterísticas [...] imitações às vezes ridículas de boulevards e de brodways, por onde a gente anda a pé e só falta derreter-se sob o sol forte como que o bom Deus ora nos favorece ora nos castiga" (MR, não paginado). Emerge nessa oposição de Freyre uma percepção relativamente crítica da modernização excludente, centrada nos projetos centralistas de poder e de reformas sociais, que se orientam por um anseio de similaridade com a modernização do centro capitalista, indiferentes às peculiaridades do contexto local.

Freyre toma a preservação de certo número de ruas "acolhedoramente estreitas" como motivo para ressaltar a oposição que está no cerne do Manifesto: a recusa do modernismo paulista, que "vê em tudo o

8. Destaquemos que o elogio da superioridade estrutural e higiênica dos mucambos ampara-se apenas em suposições exteriores. Não há nenhum tipo de referência ou dados que comprovem isto.

9, A imitação é vista em muitos casos, tanto por modernistas quanto por regionalistas, como uma forma de inferioridade e dependência cultural. Acreditamos, porém, que tal concepção tende a entender a cultura como um fenômeno de origem una, que, a partir de um centro irradiador, fornece modelos e parâmetros a serem imitados ou repelidos. A questão da renovação de novidades insere-se num importante debate acerca da questão da imitação na arte e na política brasileira. Muitos autores apontam no próprio modernismo brasileiro uma mera cópia de movimentos europeus. O que ocorre, no entanto, é mais uma forma brasileira de modernismo que uma cópia. A modernidade brasileira é diversa da europeia. Apesar de buscar na Europa suas fontes, o que se desenvolve no Brasil é uma modernidade que se dá num país pouco industrializado e com pouca tradição em movimentos sociais: nunca tivemos grandes filosofias humanistas. Schwarz (1987) entende que, ao longo de sua reprodução social, incansavelmente, o Brasil põe e repõe ideias europeias, sempre no sentido impróprio. É nessa qualidade que elas serão matéria e problema tanto para a literatura quanto para o pensamento social. Para o ensaísta, o escritor pode não saber disso, nem precisa usá-las, mas só alcança ressonância profunda e afinada caso lhes sinta, registre e desdobre - ou evite - o descentramento e a desafinação. 
que é antigo ou oriental um arcaísmo a ser abandonado" (MR, não paginado). Para o autor do Manifesto, é a um desejo irracional de destruir que o modernismo se associa. Nesse sentido, é somente mediante o resgate de comportamentos e tradições locais que ele pode encontrar uma oposição consistente.

A tradição exige símbolos, monumentos, práticas, rituais etc., que mantenham seu vigor e a materializem como linearidade histórica. Duas dimensões irrompem como significativas dessa função: a herança arquitetônica e a culinária típica do Nordeste como formas de preservação cultural e social e, sobretudo, como símbolos e alicerces da "autenticidade".

A arquitetura cumpre, como sugerido anteriormente, o papel de superioridade adaptativa e expressividade das construções locais. A culinária possui um relevo considerável, senão central na preservação dos valores, sendo dotada inclusive de uma profunda associação com a formação sociocultural e as subjetividades. Relevando seu status, o Manifesto objetiva recusar a homogeneização que ameaça dissolvê-la. "A necessidade de serem todos defendidos pela gente do Nordeste contra a crescente descaracterização da cozinha regional". É significativo notar que, em certo sentido, a valorização da culinária local possui uma vinculação social, ela associa-se a uma celebração dos pratos tradicionais das famílias ricas do Nordeste, contrapondo-os às novidades "estrangeiras" que começam a aparecer na culinária pernambucana (Leite, 1969).

A culinária e o sistema alimentar possuem uma importância fundamental na sociologia e na antropologia de Freyre, como o bem demonstram suas interessantes análises sobre a culinária indígena, africana e portuguesa em outros momentos de sua obra. No Manifesto regionalista, o autor realiza um inventário das práticas alimentares mais vinculadas à região. Salgados, carnes, temperos e, principalmente, doces emergem como os acepipes que compunham a alimentação regional e nacional. $\mathrm{O}$ açúcar está presente em toda a culinária do país. Doces preparados por "pretas de tabuleiro" que alimentavam a "doçura" dos senhores de engenho, glutões especializados em deliciar-se com o que de mais saboroso era oferecido pela culinária regional. A rica e saborosa culinária local possui também como principais oponentes "os estrangeiros e os do Rio". "Dos velhos engenhos da região é raro o que não tenha tido sua especialidade culinária mesmo modesta: um quibebe, ou um pirão ou farofa mais gostosa que as outras. Alguns foram famosos por seus senhores, grandes quituteiros ou simples regalões e até glutões" (MR, não paginado).

Freyre sugere a impossibilidade de preservar intacto o passado, o que resta então é a preservação de certas práticas, buscando adaptá-las aos novos tempos. Esse papel caberia, em certa medida, à mulher:
A arte da mulher de hoje estaria na adaptação das tradições da doçaria ou da cosinha [sic] patriarcal às atuais condições de vida e de economia doméstica. Nunca em repudiar tradições tão preciosas para substituí-las por comidas incaracterísticas de conserva e de lata, como as que já imperam nas casas das cidades e começam a dominar nas do interior (MR, não paginado).

A desagregação dos valores culinários assume ares de catástrofe. "Toda essa tradição está em declínio ou, pelo menos, em crise, no Nordeste. E uma cosinha [sic] em crise significa uma civilização inteira em perigo de descaracterizar-se". Caberia à mulher, então, salvaguardar essa culinária, ou essa civilização. Agente central no comando doméstico, também resta à mulher servir de guardiã daquilo que socialmente não mais possui uma sólida sustentação. Assim, a moral, a religião e o fogão, no Manifesto, são armas femininas na luta pela manutenção de um estilo de vida e pela preservação de uma identidade:

Quando a verdade é que, depois dos livros de missa, são os livros de receitas de doces e de guisados os que devem receber das mulheres leitura mais atenta. $\mathrm{O}$ senso de devoção e o de obrigação devem completarse nas mulheres do Brasil, tornando-as boas cristãs e ao mesmo tempo boas quituteiras para assim criarem melhor os filhos e concorrerem para a felicidade nacional. Não há povo feliz quando às suas mulheres falta arte culinária. É uma falta quase tão grave como a de fé religiosa. (MR, não paginado).

É por meio de um itinerário cultural pelas tradições nordestinas que Freyre, no Manifesto regionalista, deseja destacar a necessidade de que sejam preservadas as práticas mais autênticas que definem a região e conformam a própria nação brasileira. Isso é feito a partir de um esforço de compreensão do universal por meio da apreensão de um particular extremamente delimitado e, além disso, socialmente vinculado. Sob as matizes do discurso de resgate dessas tradições parece residir, em certa medida, uma (re)interpretação da identidade nacional e dos valores "autênticos" e "inautênticos" que a informam naquele contexto e que parecem possuir estreitos vínculos sociais.

\section{Considerações finais}

A ambiguidade, a contradição e o paradoxo definem o Manifesto regionalista, mas não esgotam sua interpretação como intervenção cultural explícita de um grupo intelectual no contexto dos anos 20 , bem como dos debates estéticos e políticos que o caracte- 
rizam. O projeto cultural do regionalismo de Freyre não se reduz a uma luta pela preservação de tradições culturais, mas irrompe também como disputa no cenário intelectual pela tomada e ocupação de posições sociais e simbólicas.

O Manifesto regionalista concentra-se no passado rural, o que sugere também uma oposição aos manifestos modernistas centrados no futuro, no porvir das cidades e metrópoles. Ele é perpassado pela "invenção" e retomado da tradição, que oferece, por sua vez, os alicerces para a argumentação regionalista do texto.

O passado rural colonial e seu substrato cultural também compreendem uma forma de importação e, nesse sentido, não se distingue da "imitação" modernista recusada por Freyre. É nesse sentido, portanto, que sua intervenção deve ser compreendida no interior dos debates imanentes ao campo intelectual brasileiro de então, bem como em relação às transformações sociais, políticas e econômicas que definem a configuração sócio-histórica. O modernismo de 22, bem como o Manifesto, vinculam-se, com estratégias e focos diferenciados, ao debate intelectual referente à composição de uma cultura "genuinamente brasileira", à busca de uma "identidade nacional", seja antropofágica ou um híbrido luso-colonial. Ambos se mobilizam a partir de uma interpretação da "autenticidade" e da "inautenticidade" nacional e exprimem a busca de uma "explicação" autóctone para as práticas sociais e culturais que conformaram e constituem o Brasil.

\section{Referências}

ALMEIDA, José Mauricio Gomes. A tradição regionalista no romance brasileiro. Rio de Janeiro: TopBooks, 1999.

BERMAN, Marshal. Tudo que é sólido desmancha no ar: a aventura da modernidade. São Paulo: Companhia das Letras, 1996.

BOSI, Alfredo. História concisa da literatura brasileira. São Paulo: Cultrix, 1979.

COSTA, Emília Viotti da. Da monarquia à república: momentos decisivos. São Paulo: Brasiliense, 1985.

D'ANDREA, Moema Selma. A tradição re(des)coberta: Gilberto Freyre e a literatura regionalista. Campinas: Ed. Unicamp, 1992.

FREYRE, Gilberto. Manifesto regionalista de 1926. Recife: Região, 1952. Disponível em: <http://www.unir. br/ caldas/regionalista.htm>. Acesso em: 10 nov. 2009. . Casa-grande E senzala. São Paulo: Record, 2001.

GOMES, Heloisa Toller. O poder rural na ficção. São Paulo: Ática, 1981.

IANNI, Octavio. Tipos e mitos do pensamento brasileiro. Revista Brasileira de Ciências Sociais, São Paulo, v. 17, n. 49, 2002.

LIMA, Jorge de. Obra completa. v. 1. Rio de Janeiro: Aguilar, 1958.
LIMA, Nísia Trindade. Um Sertão chamado Brasil: intelectuais e representação geográfica da identidade nacional. Rio de Janeiro: Revan, 1999.

LEITE, Dante Moreira. O caráter nacional brasileiro: história de uma ideologia. São Paulo: Pioneira, 1969.

MARX, Karl. O 18 Brumário de Luis Bonaparte. Rio de Janeiro : Paz e Terra, 1997.

MORAIS, Jorge Ventura de; RATTON JR., José Luiz. Gilberto Freyre e a articulação dos níveis micro e macro na sociologia. Revista Brasileira de Ciências Sociais, São Paulo, v. 20, n. 58, 2005.

ORTIZ, Renato. Cultura brasileira e identidade nacional. São Paulo: Brasiliense, 1985.

RIDENTI, Marcelo. Em busca do povo brasileiro: artistas da revolução, do CPC à era da TV. Rio de Janeiro: Record, 2000.

SCHWARZ, Roberto. Que horas são?: ensaios. São Paulo: Companhia das Letras, 1987.

WILliAMS, Raymond. Cultura. São Paulo: Paz e Terra, 2000 .

O campo e a cidade: na história e na literatura. São

Paulo: Companhia das Letras, 1989. 


\title{
Culture and tradition in Gilberto Freyre: an outline of interpretation of the Regionalist Manifesto
}

\begin{abstract}
This paper analyzes the defense of tradition carried out in the Regionalist Manifesto, written by Gilberto Freyre in 1926. Freyre's text joins the debate sociocultural then, through an intervention highlighted in discussions of modernism. We seek to explain how the Manifesto operates a rescue of rural colonial past, developing a clash between tradition and modernity and composing a conservative strategy for the interpretation of social change.
\end{abstract}

Keywords: tradition; rural, urban; regionalism; modernism

\section{Cultura y tradición en Gilberto Freyre boceto de interpretación del}

\section{Manifiesto Regionalista}

\section{Resumen}

Este trabajo analiza la defensa de la tradición que llevó a cabo en el Manifiesto Regionalista, escrito por Gilberto Freyre en 1926. El texto de Freyre se une al debate sociocultural que se señala a continuación, se ha destacado en los debates de la modernidad mediante una intervención. Tratamos de explicar cómo funciona el Manifiesto de un rescate del pasado rural colonial, el desarrollo de un choque entre la tradición y la modernidad, además de la composición de una estrategia conservadora para la interpretación del cambio social.

Palabras clave: tradición; rural; urbana; el regionalismo; el modernismo.

Data de recebimento do artigo: 10/05/2010

Data de aprovação do artigo: 21/02/2011 